\title{
The Evaluation of the Relation Between Nasal Polyp Etiopathogenesis and the Amount of Biofilm
}

\section{Nazal Polip Etiopatogenezi ve Biofilm Miktarı Arasındaki iliş̧kinin Değerlendirilmesi}

\author{
${ }^{1}$ Kazım Bozdemir (D), ${ }^{2}$ Elif Ersoy Çallıoğlu (D), ${ }^{3}$ Bülent Ulusoy (D), ${ }^{4}$ Selami Candan (D), 1 Serkan Serifler (iD, ${ }^{4}$ Nurcan \\ Ozyurt Koçakoğlu (iD, ${ }^{2}$ Yuce islamoğlu (iD
}

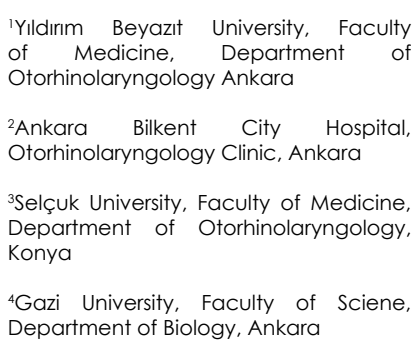

Kazım Bozdemir, Üniversiteler Mahallesi 1604. Cadde No: 9, 06800, Cankaya/ ANKARA

E-Mail: kazimbozdemir@gmail.com

\section{How to cite?}

Bozdemir K, Ersoy-Çallıoğlu E, Ulusoy B, Candan S, Serifler S, Ozyurt-Koçakoğlu $N$, islamoğlu $Y$. The Evaluation of relation the Relation Between Nasal Polyp

\begin{abstract}
Objective: To evaluate the effect of biofilm layer on polyp formation in nasal polyposis by comparing the amount of biofilm layer on polyp tissue and the normal mucosa.

Materials and Methods: This study is a prospective study. 14 patients who underwent functional endoscopic sinus surgery (FESS) for nasal polyposis were evaluated. Patients were had no history of previous FESS. Tissue samples were obtained from lower turbinate (Group $1 \mathrm{n}: 14$ ) and from nasal polyp (Group 2, n:14) of the same nasal cavity. Biofilm presence was identified using scanning electron microscopic (SEM) morphological findings. In biofilm positive samples, the presence of biofilm in less than $25 \%$ of the surface area was classified as $(+)$, between $25-50 \%$ as $(++)$, and over $50 \%$ as $(+++)$.

Results: In Group 2, with SEM imaging, (+++) biofilm presence was detected in 9 patients and (++ biofilm was detected in 5 patients. In Group 1, no biofilm was detected 8 patients, while; $(+++),(++)$, and $(+)$ biofilm presence was detected in 1,2 , and 3 patients respectively. Significant difference was found between group 1 and group 2 with respect to the amount of biofilm according to SEM $(p=0.000)$.

Conclusion: In samples, statistically significant difference was found between polyp tissue and normal mucosa in terms of the amount of biofilm. However, further studies with larger patient series are required in order to reach a definitive conclusion on the effect of biofilm on pathogenesis of polyp.
\end{abstract}

Keywords: Biofilm; Nasal Polyp; Microscopy, Electron, Scanning

öz

Amaç: Polip dokusu ve normal mukoza üzerindeki biyofilm tabakası miktarını karşıllaştırarak nazal polipoziste biyofilm tabakasının polip olusumuna etkisini değerlendirmek amaçlanmaktadır.

Materyal ve Metod: Bu çalışma, prospektif bir çalısma olup nazal polipozis nedeniyle fonksiyonel endoskopik sinüs cerrahisi (FESS) uygulanan 14 hasta değerlendirildi. Hastalar, daha önce endoskopik sinüs cerrahisi geçirmemiş hastalardan oluşmaktaydı. Doku örnekleri, aynı nazal kaviteden alt konkadan (Grup 1, n:14) ve nazal polip dokusundan (Grup 2, n:14) alindı. Biyofilm varlığı, Scanning elektron mikroskobu (SEM) morfolojik bulgular kullanılarak tanımlandı. Biyofilm pozitif örneklerde, görüntülenen yüzey alanının \%25'inden az sahada biyofilm varlığı $(+)$, \%25-50 arası (++) ve \%50' den fazla sahada biyofilm varlığ (+++) olarak sinıflandırıldı.

Bulgular: Grup 2'de SEM görüntülemede 9 hastada (+++) biyofilm mevcudiyeti saptanırken 5 hastada (++) biyofilm tespit edildi. Grup 1 'de ise 8 hastada biyofilm saptanmazken 1 hastada (+++), 2 hastada (++) ve 3 hastada (+) biyofilm varlığı saptandı. SEM bulgularına göre biyofilm miktarı açısından grup 1 ve grup 2 arasinda anlamlı fark bulundu $(p=0.000)$.

Sonuç: Örneklerde, polip dokusu ile normal mukoza arasında biyofilm miktarı açısından istatistiksel olarak anlamlı fark bulundu. Bununla birlikte, biyofilmin polip patogenezine etkisi konusunda kesin bir sonuca varmak için daha geniş hasta serileri ile yapılacak çalıșmalara intiyaç vardır.

Anahtar kelimeler: Biyofilm; Nazal Polip; Scanning-Electron Mikroskopi

\section{Introduction}

Biofilm, is the structure produced by micororganisms and characterized by mucosal inflammation and which attach to a surface and form a polymeric enlarge towards lumen in nasal cavity. They have gelatinous layer (1). Biofilm may develop in vivo a pedunculated, gelatinous structure with smooth or in vitro on inorganic surfaces and can protect surface. The etiology of nasal polyps are multifactorial micrororganism from osmotic stress, phage remnants, and although various factors such as infection, allergy, toxic components and antibiotics. Cells with this immunological factors, metabolic and hereditary structure are more resistant to antimicrobial agents diseases and autonomic dysfunction has been reported, than planktonic cells and have barriers preventing etiology is still controversial.

contact with antimicrobial agents or decreasing susceptibility to them (2). Nasal polyps are benign mucosal protrusions with multifactorial causes

There are many studies in the literature establishing that there is biofilm layer on nasal polyp tissue, which 
regresses with treatment (3-5). Although these studies indicate that biofilm layer influences nasal polyposis treatment, the role of biofilm in the etiopathogenesis of nasal polyps still remains to be elucidated.

Therefore the aim of the present study was to evaluate the effect of biofilm layer on the development of polyp in patients with nasal polyposis by comparing the amount of biofim on polyp tissue with that on adjacent normal mucosal tissue in the same nasal cavity and hence excluding other additional factors which may lead to biofilm formation.

\section{Materials and Methods}

The present study is a prospective study carried out with the approval of local ethics committee (13.11. 2019, No.111) and informed consent of patients.

\section{Subjects}

14 patients $(4 \mathrm{~F}, 10 \mathrm{M})$ who underwent endocopic sinus surgery between 2019-2020 for nasal polyposis were evaluated. Detailed history was elicited and physical examination and radiological investigation was carried out. All patients had history of nasal steroid agent and antibiotherapy use. None had undergone endoscopic sinus surgery previously. Tissue samples at the size of $3 \times 3 \mathrm{~mm}$ were obtained during operation from nasal polyp tissue (group 2,study group) and normal inferior turbinate (group 1, control grup) of the same nasal cavity. Patients with immune supression, fungal sinusitis, and ciliary disorders such as granulomatous disease and cystic fibrosis were excluded from the study.

In Group 1 and Group 2 patients, biofilm was identified by using SEM morphological findings. The presence and amount of biofilm was compared between two groups.

\section{Scanning Electron Microscopic (SEM) evaluation}

For scanning electron microscopy, tissue samples were fixed with $2.5 \%$ glutaraldehyde $(\mathrm{pH} 7.2$, sodium phosphate buffer) after they were rinsed three times in sodium phosphate buffer, dehydrated with from 50 to $100 \%$ alcohol series. After the dehydration, the samples were dried with hexamethyldisilazane (HMDS). Finally, they were mounted on aluminium SEM stubs. The stubs were covered with gold by using a sputter coater (Polaron SC 502) and samples were examined and photographed with a JEOL JSM 6060 LV SEM to determine biofilm presence in $10 \mathrm{kV}$.

Biofilmpresencewasidentified usingSEMmorphological findings such as 3-dimensional structure, variation in the dimension of microorganisms embedded in polyp matrix, and residue of multiple layers of tissue and microorganism. $3 \times 3 \mathrm{~mm}$ size samples from nasal cavity were examined. With this examination, the presence of biofilm was evaluated and in biofilm positive samples, similar to previous studies, $(6,7)$ the presence of biofilm in less than $25 \%$ of surface area was classified as (+), between \%25-50 as (++) and over \%50 as (+++).

\section{Statistical Evaluation}

The statistical analysis of the data obtained was carried out with SPSS Statistics program. As categorical variables were used, descriptive statistics were expressed with frequancy and percentage and in two by two comparisons chi-square test was used. $\mathrm{p}<0.05$ value was considered significant for all results.

\section{Results}

14 patients who have undergone endoscopic sinus surgery were evaluated in the present study. There were 4 female and 10 male patients. Mean age of the patients was 46,62 (34-66). In SEM examination; in Grup 2, biofilm presence was detected at the degree of $(+++)$ (Figure la-d) in 9 patients and at the degree of $(++)$ in 5 patients (Table 1). In Group 1, no biofilm was detected in 8 patients, (figure 2a-d), 1 patient had $(+++), 2$ patients had $(++)$, and 3 patients had $(+)$ biofilm presence (Table 1). Significant difference was found between Group 1 and Group 2 in terms of amount of biofilm detected with SEM ( $p=0.000$ ) (Table 1).

Table 1: Biofilms levels detected in nasal polyps and inferior turbinates

\begin{tabular}{llllll}
\multicolumn{5}{c}{ SEM grading of biofilm formation } & \\
$\begin{array}{l}\text { Tissue sample } \\
\begin{array}{l}\text { Polyp } \\
(n=14)\end{array}\end{array}$ & None & + & ++ & +++ & $P^{*}$ \\
$\begin{array}{l}\text { Turbinate } \\
(n=14)\end{array}$ & 8 & 3 & 2 & 1 & \\
\end{tabular}

${ }^{*} p$ value shows the results of Chi square test

Figure 1. A- D: $(+++)$ biofilm formation in nasal polyps on SEM;

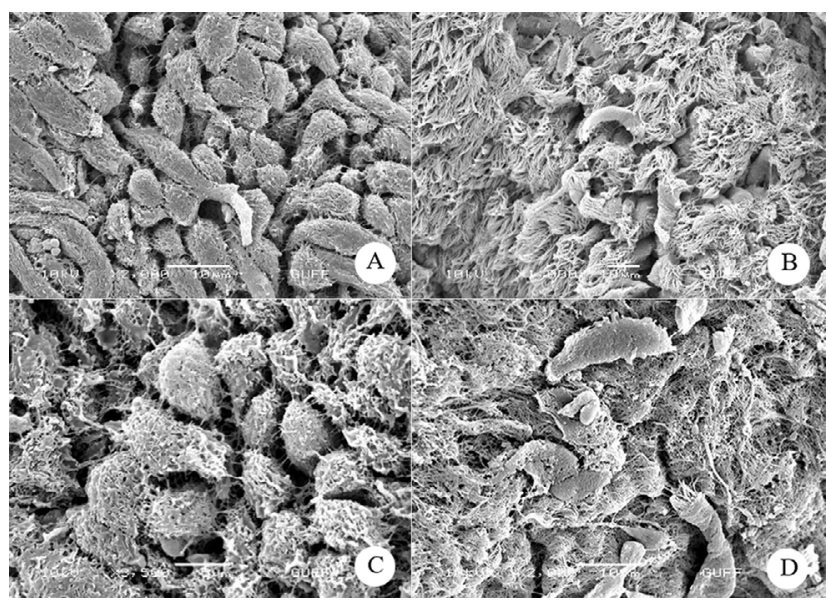

Figure 2. A-D: Absence of biofilm on SEM in the mucosa of the inferior turbinate.

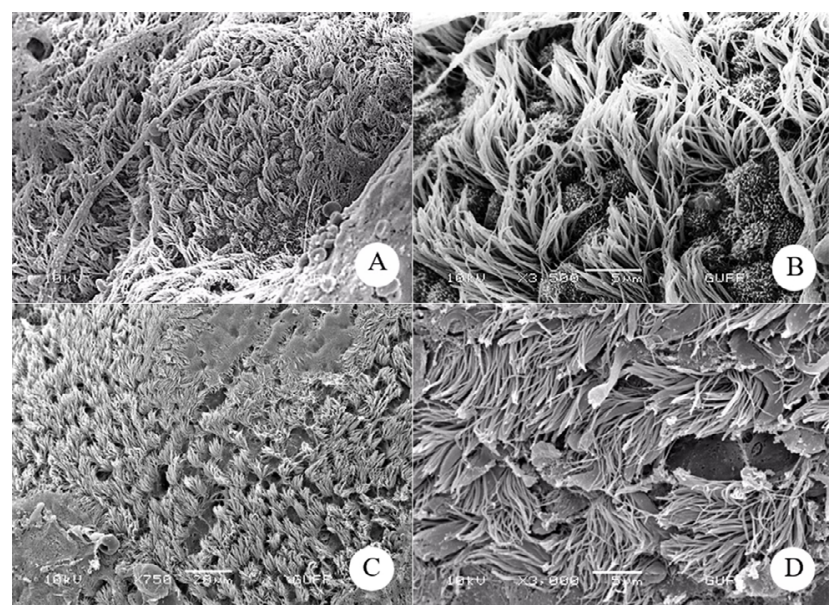




\section{Discussion}

Biofilm may protect microorganisms from osteomic stress, phage residues, toxic compounds and antibiotics. They hence defend bacteria as well as leading to the enhancement of damage in host by producing endotoxins and other virulance factors. Many studies have demonstrated the presence of biofilm in at least \%65 of human bacterial infections (8-11).

Biofilms can be detected in the majority of patients with chronic rhinosinusitis $(12,13)$. Sanclement et al. (12) determined the presence of bi ofilm in 24 out of 30 affected individuals and in 0 out of 4 controls subjects. Galli et al. (13) have reported that there may be marked destruction of the ciliated epithelium in the biofilm development. The presence of biofilm on the mucosa of chronic rhinosinusitis patients can be a cause for the persistent tissue inflammation as well as antibiotic resistance and antimicrobial therapy failures (14). Recent research has revealed that the presence of the bacterial biofilms may predispose patients to worse outcomes after sinus surgery (15).

In addition, chronic sinusitis is most likely a manifestation of the interaction of several host and environmental factors with various microorganisms. Some studies have demonstrated that epigenetic influences could induce a disease's development (16).

The presence of biofilm on nasal polyp tissue was demonstrated in many studies (3-5) nevertheless, etiology of nasal polyposis and the role of biofilm tissue still remains to be elucidated. Zernotti et al. (3) determined the presence of biofilm in 9 of 12 patients who underwent operation for nasal polyposis and established that biofilms give rise to tissue hyperplasia by increasing nasal mucosa damage and the number of inflammatory cells. In many studies, it has been proposed that biofilm tissue may set the stage for development of nasal polyps (9-11).

Likewise, our findings also support the aforementioned suggestions as regards the association of biofilms with nasal polyps. In the present study, nasal polyp tissue and adjacent normal nasal mucosa tissue were obtained from the same nasal cavity for evaluation, which eliminated other factors which may lead to biofilm formation. This aspect of the study helped to support the role of biofilm in the etiopathogenesis of nasal polyposis from a different perspective compared to other studies on etiopathogenesis. In addition, in view of this association, it would be reasonable to state that we may be in need of modifications in the management strategies of nasal polyps.

Contrary to these studies, there are studies reporting that biofilm tissue has no effect on polyp etiology (17). Berezza et al. (17) reported that biofilms were be present in patients undergoing sinus surgery for chronic rhinosinusitis with nasal polyps and also in healthy controls.

\section{Conclusion}

According to our findings nasal polyps are associated with bacterial biofilm formations. However, the role of biofilms in the etiology of nasal polyps is unclear. Further studies with larger patient series rare required in order to reach a definitive conclusion on the impact of biofilm on the etiopathogenesis of polyp.

\section{References}

1.Leone S, Molinaro A, Alfieri F, et al. The biofilm matrix of Pseudomonas sp. OXl grown on phenol is mainly constituted by alginate oligosaccharides. Carbohydr Res 2006;341: 2456-61.

2.O'Toole G, Kaplan HB. Biofilm formation as microbial development. Annual Reviews in Microbiology, 2000; 49-79.

3.Zernotti ME, Angel Villegas N, Roques Revol M, Baena-Cagnani CE, Arce Miranda JE, Paredes ME. Evidence of bacterial biofilms in nasal polyposis. J Investig Allergol Clin Immunol 2010; 20: 380-5.

4.Mladina R, Poje G, Vukovi K, Risti M, Musi S. Biofilm in nasal polyps. Rhinology 2008; 46:302-7.

5.Korkmaz H, Ocal B, Tatar EC, et al. Biofilms in chronicrhinosinusitis with polyps: is eradicationpossible? Eur Arch Otorhinolaryngol 2014; 271:2695-702.

6.Tatar EC, Tatar I, Ocal B, et al. Prevalence of biofilms and their response to medical treatment in chronic rhinosinusitis without polyps. Otolaryngol Head Neck Surg 2012; 146:669-75.

7.Saylam G, Tatar EC, Tatar I, Ozdek A, Korkmaz H (2010). Association of adenoid surface biofilm formation and chronic otitis media with effusion. Arch Otolaryngol Head Neck Surg 2010; 136:550-5.

8.Vuong C, Kocianova S, Voyich JM, et al. (2010) A crucial role for exopolysaccharide modification in bacterial biofilm formation, immune evasion, and virulence. J Biol Chem 2010; 279:54881-6.

9.Tripathi A, Kern R, Conley DB, et al. Staphylococcal exotoxins and nasal polyposis: analysis of systemic and local responses. Am J Rhinol 2005; 19:327-33.

10.Seiberling KA, Conley DB, Tripathi A, et al. Superantigens and chronic rhinosinusitis: detection of staphylococcal exotoxin in nasal polyps. Laryngoscope 2005; 115: 1580-5.

11.Bernstein JM, Ballow M, Schliever PM, Rich G, Allen C, Dryja D. A superantigen hypothesis for the pathogenesis of chronic hyperplasic sinusitis with massive nasal polyposis. Am J Rhinol 2003;17: 321-6.

12.Sanclement JA, Webster $\mathrm{P}$, Thomas J, Ramadan $\mathrm{HH}$. Bacterial biofilms in surgical specimens of patients with chronic rhinosinusitis. Laryngoscope 2005; 115: 578-82.

13.Galli J, Calò L, Ardito F, et al. Damage to ciliated epithelium in chronic rhinosinusitis: what is the role of bacterial biofilms? Ann Otol Rhinol Laryngol 2008; 117:902-8.

14.Singh P, Mehta R, Agarwal S, Mishra P. Bacterial biofilm on the sinus mucosa of healthy subjects and patients with chronic rhinosinusitis (with or without nasal polyposis). J Laryngol Otol 2015; 129: 46-9.

15.Bendouah Z, Barbeau J, Hamad WA, Desrosiers M. Biofilm formation by Staphylococcus aureus and Pseudomonas aeruginosa is associated with an unfavorable evolution after surgery for chronic sinusitis and nasal polyposis. Otolaryngol Head Neck Surg 2006; 134:991-996.

16.Sanderson AR, Leid JG, Hunsaker D. Bacterial biofilms on thesinus mucosa of human subjects with chronic rhinosinusitis. Laryngoscope 2006; 116:1121-6.

17. Bezerra TF, Pádua FG, Ogawa Al, Gebrim EM, Saldiva PH, Voegels RL. Biofilm in chronic sinusitis with nasal polyps: pilot study. Braz J Otorhinolaryngol 2009; 75:788-93. 